\title{
CERNICA U DOBA KOSAČA
}

\author{
Radmilo B. PEKIĆ \\ Filozofski fakultet u Kosovskoj \\ Mitrovici \\ Filipa Višnjića b.b. \\ SRB - 38220 Kosovska Mitrovica \\ E-pošta: bijeljani@yahoo.com
UDK: 94 (497.6 Cernica):929.5 KOSAČE 908(497.6 Cernica):929.5 KOSAČE
Izvorni znanstveni rad
Primljeno: 1. veljače 2017 \\ Prihvaćeno: 5. travnja 2017 \\ Rad je lektorirala Olivera ŠOLAJA
}

\section{Sažetak}

U istorijskoj nauci je odavno istaknuto da je srednjovjekovna Cernica bila jedna od karavanskih stanica na "Dubrovačkom drumu" i da je postepeno prerasla u trg. U neposrednoj blizini nalazio se Ključ, jedan od najvažnijih gradova vlasteoske porodice Kosača. Kod Cernice i pored grada Ključa, Sandalj Hranić i njegov naslednik herceg Stefan Vukčić Kosača, kontrolisali su putnu komunikaciju, koja je povezivala Dubrovnik sa Bosnom i Srbijom. Trgovci koji su se kretali pomenutim "Dubrovačkim drumom" u Cernici i njenoj okolini napadani su i pljačkani od podanika Kosača, često i uz blagoslov svojih sizerena. $\mathrm{Na}$ temelju neobjavljenih i objavljenih dubrovačkih izvora, terenskog i ranijih istraživanja, u radu su, pored osvrta na najraniju prošlost, prezentovane privredne i kulturne prilike stanovništva u Cernici u doba uprave vlasteoske porodice Kosača.

Ključne riječi: Cernica; Ključ; Kosače; Sandalj Hranić; Stefan Vukčić; Dubrovnik. 
Pod obroncima Babe planine, čiji je najveći vrh Djed (1735 m), ispod povije koja razdvaja Gatačko polje od nižeg Cerničkog polja u plodnoj kotlini nalazi se Cernica. Kotlina je omeđena sa tri strane: prevojem Kobilja glava, selom Stepan i Kamenim brdom, dok se u pravcu jugoistok-sjeverozapad proteže Cerničko polje, dužinom oko $4 \mathrm{~km}$ i prosječnom širinom $1 \mathrm{~km}$, na nadmorskoj visini od 815 do 850 metara. U kotlini na sjevernom dijelu polja nalazi se selo Ključ i istoimeni srednjovjekovni grad - tvrđava, dok je jugoistočno smješteno selo Zagradci na $915 \mathrm{mnv}$.

Budući da nedostaju istorijski izvori, nije poznat nastanak naselja Cernica. Područje Cernice bogato je arheološkim lokalitetima iz antičkog i srednjovjekovnog perioda, koji svjedoče o kontinuitetu naseljenosti. ${ }^{1}$

O istoriji srednjovjekovne Cernice određena saznanja pružaju dubrovački hroničari. U istorijskoj literaturi je istaknuto da je Cernica bila seoski trg još u doba kada se ovo područje nalazilo u okviru srednjovjekovne srpske države. ${ }^{2}$

U administrativnom pogledu Cernica je pripadala župi Gacko koja je bilo u sastavu Zahumlja, odnosno Humske zemlje. Ovo je područje u XII vijeku bilo u sastavu države Nemanjića, što potvrđuje poznata Nemanjina povelja izdata Splićanima 1190-1194. godine, na osnovu koje je konstatovano da je, kao udeoni knez, Zahumljem upravljao treći Nemanjin sin Rastko, prije nego što je otišao na Svetu Goru i postao monah Sava. ${ }^{3}$

O značaju ovoga područja za srednjovjekovnu srpsku državu svjedoči i činjenica da se u "zemlji zvanoj Gacko" 1276. godine odigrala odlučujuća bitka između kralja Uroša I (1243-1276) i njegovog sina Dragutina (1276-1282). Epilog bitke je bio da je Dragutin došao na presto Srbije, a kralj Uroš I se povukao i umro kao monah u nekom od manastira Zahumlja. ${ }^{4}$

1 Arheološki leksikon Bosne i Hercegovine, 3, Arheološka nalazišta regija 1425, Zemaljski muzej Bosne i Hercegovine, Sarajevo 1988, str. 139, 142, 146.

2 Богумил Храбак, Из старије прошлости Босне и Херцеговине, књ. IV, Ауторско издање, Београд 2008, стр. 64.

3 Зборник средњовековних ћириличних повеља и писама Србије, Босне и Дубровника, књ. 1, (1186-1321), (прир. В. Мошин, С. Ћирковић, И. Синдик), Историјски институт, Београд 2011, стр. 63-64.

4 Историја Српског народа, књ. I, Српска књижевна задруга, Београд $1994^{2}$, стр. 356 (С. Ћирковић). 
U doba vladavine kralja Stefana Dečanskog, a i kasnije, gospodar Gacka a samim tim i Cernice bio je vojvoda Vojin, rodonačelnik poznatih Vojinovića i Altomanovića. Na temelju ispisa K. Jirečeka koji se čuvaju u Bugarskoj akademiji nauka, G. Tomović nas obavještava da je Vojin postupao agresivno prema Dubrovčanima. Zbog toga je dubrovačko Veliko vijeće na sjednici održanoj 24. aprila 1326. godine donijelo odluku da se uputi žalba kralju Srbije na njegovog podanika - "baro et vaxilifer Voynus".

Vlastelinstvo od oca vojvode Vojina i braće naslijedio je Vojislav Vojinović, koji je sve do 1363. godine upravljao ovim područjem. ${ }^{6} \mathrm{Kada}$ su Dubrovčani u poslanstvo slali Ivana Gundulića knezu Vojislavu, on je išao u Gacko.?

Kneza Vojislava Vojinovića naslijedio je sin njegovog brata, župana Altomana Vojinovića i Ratoslave Mladenović, znameniti Nikola Altomanović, koji je takođe upravljao ovim područjem. ${ }^{8}$ Nakon poraza Nikole Altomanovića 1373. godine, bosanski ban od 1377. godine kralj Tvrtko I Kotromanić (1354-1391) priključio je Gacko i Cernicu bosanskoj državi. ${ }^{9}$

U sklopu bosanske države, Cernicom i širim područjem Humske zemlje i Travunije, upravljala je vlasteoska porodica Kosače čiji uspon u pojedinostima nije moguće pratiti zbog nedostatka istorijskih izvora. U istoriografiji preovladava mišljenje da su Kosače porijeklom iz gornjeg Podrinja, gdje su prvobitno imali svoje posjede u srednjovjekovnoj Župi Osanici. Na lijevoj strani rijeke Osanice kraj sela Ilovače,

5 Гордана Томовић, Војиновићи, у: Срђан Рудић (прир.), Споменица академика Симе Ћирковића, Зборник радова, књ. 25, Историјски институт, Београд 2011, стр. 356.

6 Раде Михаљчић, Крај српског иарства, Knowledge, Београд 2001², стр. 40, 234; Историја Српског народа, књ. I, стр. 499, 578 (С. Ћирковић).

7 Јорјо Тадић, Писма и упутства Дубровачке републике, књ. I, Зборник за историју, језик и књижевност, III одељење, књ. IV, Српска краљевска академија, Београд 1935, стр. 6-7.

8 Гордана Томовић, Морфологија ћириличних натписа на Балкану, Посебна издања, књ. 16, Историјски институт, Београд 1974, стр. 75, бр. 60; Г. Томовић, Војиновићи, стр. 361-363.

9 Сима Ћирковић, Историја средюовековне босанске државе, Српска књижевна задруга, Београд 1964, стр. 134-135; Г. Томовић, Војиновићи, стр. 363. 
jugozapadno od Goražda i danas postoji naselje Kosače, za koje se smatra da je postojbina vlasteoskog roda Kosača. ${ }^{10}$

$\mathrm{Na}$ suprot navedenom, prema vijestima dubrovačkih hroničara i kontroverznog M. Orbinija, Kosače vode porijeklo iz Rudina. Naime, sin neimenovanog kneza Rudina, Vuk zvani Hrana rođen 1317. godine, zbog ubistva u lovu Branka Rastislavića pobjegao je u Ugarsku a zatim je došao na dvor cara Dušana koji mu je na upravu dodijelio Rudine. Po povratku u Rudine, njega je iz krvne osvete ubio rođak Branka Rastislavića. ${ }^{11}$

Iza ubijenog kneza Rudina Vuka Hrane ostao je sin Vlatko, koji je kasnije postao znameniti vojvoda Vlatko Vuković. ${ }^{12}$

Zahvaljujući istraživanjima M. Dinića, saznajemo da se Kosače u pisanim izvorima prvi put pominju, i to kao vlasi, 1379. godine. Naime šestorica vlaha: Bogut Kresojević, Kalojurk Merčetić, Vlatko Bogutović, Stefan Merčetić, Dabiživ Boban i Gojko Kresojević, obavezali su se Stjepanu Lukareviću da će u roku od dva mjeseca prevesti 100 tovara soli za Zorana Milogostića i Miladina Hranislavića u Praču ili u Goražde, do trga vlaha Kosača, pod kaznom. Cijena prevoza iznosila je 10 perpera za svaki prevezeni tovar. ${ }^{13}$

10 ŠEFIK BeŠLagić, Selo Kosače i njegovi spomenici, Naše starine VI, Godišnjak Zavoda za zaštitu spomenika kulture Narodne Republike Bosne i Hercegovine, Zavod za zaštitu spomenika kulture Bosne i Hercegovine, Sarajevo 1959, str. 243; Сима Ћирковић, Косаче у историографији, у: Радослав Братић (прир.), Српска проза данас, Косаче оснивачи Хериеговине, Ћоровићеви сусрети прозних писаца у Билећи, Научни скуп историчара у Гацку одржан 20-22. септембра 2000. године, Просвјета, Фонд Светозар и Владимир Ћоровић, Билећа-Гацко-Београд 2002, стр. 209-220.

11 Мавро Орбин, Кральевство Словена (Превео: Здравко Шундрица, коментари: Сима Ћирковић), Српска књижевна задруга, Београд 1968, стр. 177-178; Mavro Orbini, Kraljevstvo Slavena (prevela Snježana Husić; priredio i napisao uvodnu studiju Franjo Šanjek), biblioteka "Povijest hrvatskih političkih ideja", kolo 1, knjiga 2, Golden marketing, Narodne novine, Zagreb 1999, str. 440-441.

12 Ђуро Тошић, Родоначелник племена Косача - војвода Влатко Вуковић, y: Радослав Братић (прир.), Српска проза данас, Косаче оснивачи Хериеговине, Ћоровићеви сусрети прозних писаца у Билећи, Научни скуп историчара у Гацку одржан 20-22. септембра 2000. године, Просвјета, Фонд Светозар и Владимир Ћоровић, Билећа - Гацко Београд 2002, стр. 243-260.

13 DADU, Deb. Not. sv. 8, f. 169r (1. V 1379); Михаило Динић, Српске земле у средюем веку, Српска књижевна задруга, Београд 1978, стр. 182. 
Kosače se, izuzev Goražda, pominju i u Kalinoviku. Istaknuti istraživač srednjovjekovnih spomenika Š. Bešlagić skrenuo je pažnju na stećak u selu Vlahovlju u opštini Kalinovik na kojem je pronašao natpis u kojem se pominje pokojnica krstjanica Beoka, kći Pribislava Kosače. ${ }^{14}$ Pored toga, istaknuto je da se sredinom tridesetih godina XV vijeka pominju četiri kuće Kosača. ${ }^{15}$

Početak uzdizanja ove vlasteoske porodice vezuje se za vojvodu Vlatka Vukovića, koji se u izvorima prvi put pominje 1378. godine. Pod komandom Vlatka Vukovića istaknutog borca protiv prodora islama na Balkan, Osmanlije su u dva navrata potučeni i to na Rudinama 1386. i kod Bileće 1388. godine. Opšte je poznato i da je vojvoda Vlatko Vuković komandovao lijevim krilom u znamenitom Kosovskom boju. ${ }^{16}$

Vlatka Vukovića koji nije imao muških potomaka, od 1392. godine naslijedio je sin njegovog brata Hrane, sinovac Sandalj, koji je po tadašnjem običaju nosio patrimonialno prezime Hranić. Nakon sukoba i zarobljavanja vojvode Radiča Sankovića, savjetovano je vojvodi Sandalju Hraniću da ga pošalje svojoj kući u Drinu, što nameće pretpostavku o mjestu njihova življenja. ${ }^{17}$ Međutim, i ovo pitanje ostaje otvoreno, jer ne znamo dali je riječ o porodičnoj kući ili je navedenu kuću Sandalj stekao, poput onih u Dubrovniku, Kotoru ili u Veneciji. ${ }^{18}$

Jačanjem porodične moći, Kosače su uvećavali svoje posjede, te su u XV vijeku vladali područjem od Prijepolja, Pljevalja, Nikšića i Boke kotorske do Cetine, a tokom vladavine svoju vlast su proširili i na čitavu Humsku zemlju, pa i izvan njenih granica. ${ }^{19}$

14 Š. BeŠLagić, Selo Kosače i njegovi spomenici, str. 243.

15 Константин Јиречек, Историја Срба, књ. ІІ, Слово Љубве, Београд $1981^{2}$, стр. 39.

16 Ђ. Тошић, Родоначелник племена Косача - војвода Влатко Вуковић, стр. 243.

17 М. Динић, Српске земъе у средюем веку, стр.182.

18 Nada Grujić - Danko Zelić, Palača vojvode Sandalja Hranića u Dubrovni$k u$, Anali Zavoda za povijesne znanosti HAZU u Dubrovniku 48, Dubrovnik 2010, str. 47-132; Б. Храбак, Из старије прошлости Босне и Хериеговине, књ. I, Ауторско издање, Београд 2003, стр. 92-94.

19 Вељан Атанасовски, Пад Херцеговине, Народна књига, Београд 1979, стр. 10. 
O Cernici iz doba vojvode Vlatka Vukovića nemamo značajnijih saznanja, izuzev postojanja carine iz 1378. godine. ${ }^{20}$ Tek su od vremena uprave vojvode Sandalja Hranića brojniji podaci o Cernici. Pored Blagaja i Novog, Cernica i utvrđeni grad Ključ bili su jedno od omiljenih mjesta u kojima su rezidirali i provodili dosta vremena velikaši iz kuće Kosača. Kada je Ključ podignut, nije poznato. Narodno predanje vezuje ga za Grke, koji su napustili ove prostore. Neki smatraju da je Ključ sagradio Sandalj Hranić, koji je raspolagao ogromnim prihodima od carina, trgovine i svoje imovine, a značajne svote novca davao je u depozit. U Ključu kod Cernice je 1410. godine Sandalj izdao povelju o prodaji Ostrvice Mlečanima. ${ }^{21}$ Iste godine, Dubrovčani su protestovali zbog naplate carine u Cernici. Međutim, carina u Cernici održala se i u kasnijem periodu, u doba Stefana Vučića Kosače. ${ }^{22}$

Pored toga što je u Ključu izdavao povelje, u ovo mjesto su u posjetu Sandalju često dolazili dubrovački poslanici. Početkom 1419. godine Sandalj Hranić žalio se Dubrovčanima na Ivana, sina Lampre Crijevića, da je držao jedno njegovo selo u Konavlima u vrijeme dok je Petar Pavlović gospodario čitavom tom teritorijom. Tim povodom je pokrenuta istraga u Dubrovniku, ali i u Cernici. Naime, dubrovački poklisari su se, prema nalogu vlade po ovom pitanju, najviše raspitivali u Cernici. ${ }^{23}$

Porodicu Kosača su, u više navrata, posjećivali i liječili dubrovački ljekari, što je istaknuto u brojnim radovima. U nekoliko navrata ljekari iz Dubrovnika dolazili su Sandalju, međutim nisu se uvijek mogli odazvat pozivu. Na osnovu prepiske koju je objavio N. Mandić i drugi vidimo da se Sandalj liječio u Samoboru. Interesantan je podatak da je Sandalj Hranić imao problema sa želucem, naročito tokom konzumiranja sira. Pored ostalog ljekari su mu zabranjivali mliječne proizvode, ljuto, ribu, povrće, slano meso, a umjesto crnog

20 Константин Јиречек, Трговачки путеви и рудници Србије и Босне у средњем вијеку, Зборник Константина Јиречека I, Посебна издања, књ. CCCXXVI, Одељење друштвених наука, књ. 33. Српска академија наука, Београд 1959, стр. 289.

21 Marko Šunjić, Bosna i Venecija (odnosi u XIV i XV st.), HKD Napredak, Sarajevo 1996, str. 129-131; Б. Храбак, Из старије прошлости Босне и Хериеговине, књ. III, Ауторско издање, Београд 2004, стр. 52.

22 Десанка Ковачевић-Којић, Градска насеља средновјековне босанске државе, Веселин Маслеша, Сарајево 1978, стр. 92-93.

23 Михаило Динић, Из српске историјесредюега века (пр. С. Ћирковић В.Ђокић), Equilibrium, Београд 2003, стр. 424. 
preporučivali su mu bijelo vino. Nakon jedne Sandaljeve molbe da ga posjeti ljekar, Dubrovačka vlada je na molbu pozitivno odgovorila i uputila u Samobor opštinskog ljekara, specijalizovanog za unutrašnje bolesti, hirurga Ivana iz Padove. U njegovoj pratnji je bio i vlastelin Nikola Đorđić. Iako neki smatraju da je riječ o Samoboru na Drini, najvjerovatnije da se Sandalj liječio u Samoboru kod Cernice, za koje dubrovački pisari ponekad navode da pripada Cernici. Da se radilo o Samoboru kod Gacka, na pretpostavku navodi i činjenica da su se nakon provedenih mjesec dana liječeći Sandalja, hirurg Ivan i vlastelin Nikola Đorđić nalazili u Cernici, kada im je stigla naredba da se vrate u Dubrovnik. ${ }^{24}$

Neki raniji istraživači pominju tvrđavu Ključ kao prijestolnicu vojvode Sandalja, kasnije hercega Stefana i njegovih sinova. ${ }^{25}$

Početkom novembra 1433. godine jedan od bliskih i odanih ljudi Sandalju Hraniću, Stanihna Stanković Maleševac je optužen da je Vukca Miokanovića okovao i bacio u tamnicu u Ključu. ${ }^{26}$

Nakon smrti Sandalja Hranića 1435. godine trebalo je obnoviti ugovore između njegovog nasljednika Stefana Vukčića Kosače i Dubrovčana. Neki od pregovora vodili su se u Ključu. ${ }^{27} \mathrm{U}$ Ključu je početkom aprila 1443. godine vojvoda Stefan Vukčić Kosača izdao priznanicu Dubrovčanima da je primio nasljedstvo od Sandaljeve udovice, odnosno svoje strine Jelene, ćerke kneza Lazara, ranije supruge Đurđa II Balšića. ${ }^{28}$

24 Risto Jeremić - Jorjo Tadić, Prilozi za istoriju zdravstvene kulture starog Dubrovnika II, Biblioteka Centralnog higijenskog zavoda, Beograd 1939, 142; Vojka Besarović, Italijani - Dubrovački ljekari u Bosni, Prilozi XX/21, Instituta za istoriju, Sarajevo 1985, str. 253; PAvo Žıvković, Dubrovačkobosansko-humska suradnja na polju zdravstvene kulture tijekom XIV i XV stoljeća, Anali Zavoda za povijesne znanosti HAZU u Dubrovniku, sv. 26, Dubrovnik 1998, str. 70-72, 67-76; Novak Mandić, Osnivači Hercegovine, Autorsko izdanje, Gacko 2007, str. 73-75; E. Kurtović, Veliki vojvoda bosanski Sandalj Hranić Kosača, Institut za istoriju, Sarajevo 2009, str. 326-328.

25 Hamdija Kreševljaković - Hamdija Kapidžić, Stari hercegovački gradovi, Naše starine, II, Godišnjak Zavoda za zaštitu spomenika kulture Narodne Republike Bosne i Hercegovine, Zavod za zaštitu spomenika kulture Bosne i Hercegovine, Sarajevo 1954, str. 19.

26 DADU, Lam. de for. sv. 10, f. 93v (2. XI 1433).

27 Сима Ћирковић, Стефан Вукчић Косача и юегово доба, Научно дело, Београд 1964, стр. 14.

28 Marko Vego, Naselja bosanske srednjovjekovne države, Svjetlost, Sarajevo 1957, str. 55. 
Krajem 1455. godine herceg Stefan je u Ključu izdao dokument kojim je regulisao prava svoje buduće supruge Barbare Lihtenštajn, međutim, brak nije sklopljen. Kasnije je, tokom sukoba koji je izbio između hercega Stefana i sina mu Vladislava, iz Dubrovnika aprila 1462. godine upućen Bartol Gučetić s nalogom da izmiri oca i sina. Gučetić je dobio upustva da hercega Stefana potraži u Blagaju, Humu ili u Ključu. Takođe mu je sugerisano da će u Cernici naći ljude i konje koji treba da ga odvedu Vladislavu. ${ }^{29}$

Pored Ključa u dubrovačkim izvorima tokom XV vijeka pominje se i Podključ. ${ }^{30}$

U istorijskoj literaturi odavno je istaknuto da je u Podključu poginuo vlastelin Radonja Ratković za svog gospodara vojvodu Sandalja. Spomenik, odnosno stećak sa isklesanim natpisom Radonje Ratkovića nalazio se na lokalitetu Ćućenica u Cernici, sve dok nije dislociran 60 -tih godina prošlog vijeka, pred Vojni muzej u Beograd. ${ }^{31}$

U Cerničkom polju ispod tvrđave Ključ herceg Stefan je imao svoje posjede, što svjedoče sačuvani toponimi iz doba Osmanlijske uprave. ${ }^{32}$

Za razliku od današnjeg vremena, gdje su kuće u Cernici smještene na rubu polja i strmim stranama, na osnovu toponima i sačuvane tradicije, evidentno je da je u srednjem vijeku glavno naselje bilo $\mathrm{u}$ Cerničkom polju. Uz sam stari drum na lokalitetu Ćućenica pored nekropole postoje ostaci građevina. Ovaj dio polja Cerničani i danas nazivaju Gradom a ponekad i Čaršijom. U današnje vrijeme koristi se kao sjenokos i za ispašu stoke.

Cernica i tvrđava Ključ bili su strateški značajno mjesto za vlastelu Kosače jer su sa ovog područja kontrolisali poznati Dubrovački drum koji je išao preko Trebinja u pravcu Bileće, Trnovice, Kobilje

29 С. Ћирковић, Стефан Вукчић Косача и юегово доба, стр. 218, 248.

30 Д. Ковачевић-Којић, Градска насеља средюовјековне босанске државе, стр. 119.

31 "Ovdje leži Radonja Ratković pogiboh pod gradom pod Ključem za svoga gospodara vojvodu Sandalja." MARко VEGo, Zbornik srednjovjekovnih natpisa Bosne i Hercegovine, III, Zemaljski muzej, Sarajevo 1964, str. 32-33.

32 U popisu Hercegovine iz 1585. godine zabilježene su Hercegove livade ispod tvrđave Ključ u Cernici. Vidi: Ahmet Aličić, Katastarski popis elajeta Bosna, Opširni katastarski popis za oblast Hercegovinu iz 1585. godine, Sarajevo 2014, str. 249. 
glave, da bi se dalje, niz Kameno brdo, spuštao u Cernicu i Ključ, a zatim bi, preko Gacka i Čemerna, izbijao na Drinu. ${ }^{33}$

Zahvaljujući Dubrovačkom drumu, kroz Cernicu su prolazili mnogi putnici i trgovci. Takođe, trg u Cernici bio je privlačan za mnoge poslovne ljude, gdje je prodavana stoka, tkanine, vosak i druga raznovrsna roba. Pojačan protok ljudi i robe, omogućio je drumskim razbojnicima bogatiji plijen, te stoga su češće presretali i pljačkali. Napadi na karavane u Gacku zabilježeni su još početkom XIV vijeka. ${ }^{34} \mathrm{U}$ doba uprave Kosača, razbojništvo i otimačina na ovom području bili su intenzivniji. Trgovcima i raznim putnicima, naročito je opasno bilo proći Kameno brdo, koje počinje, iznad Korićke jame, iza prevoja, i pruža se uvalom iznad Cerničkog polja. I pored toga što je u ovom kraju opšte poznat lokalitet, E. Kurtović koji je pisao o Kamenom brdu, na osnovu geografskih karata predlaže nam gdje bi trebalo tražiti Kameno brdo. ${ }^{35}$

U Dubrovačkom arhivu nalaze se brojni dokumenti u kojima su evidentirane pljačke i razbojništva počinjeni na području Cernice i njene okoline. Na razne prestupe počinjene na području Gacka, Cernice i Kamenog brda, pažnju su skrenuli i o njima objelodanili brojne signature raniji istraživači, između ostalih: M. Dinić, D. Kojić-Kovačević, B. Hrabak, P. Živković, N. Mandić i drugi.

Marta 1411. godine, u Kamenom brdu opljačkan je Radovin Kvalković, kojem je otuđen jedan mač vrijednosti osam perpera. ${ }^{36}$

Dana 15. aprila 1411. godine dvojica trgovaca, Bogmil i Brajko, podnijeli su tužbu protiv Grubača Kopića. U optužnici su naveli da ih je deset dana ranije, 5. aprila, na proputovanju, u Gacku opljačkao

33 К. Јиречек, Трговачки путеви и рудници Србије и Босне у средюем вијеку, стр. 288-289.

34 Душанка Динић-Кнежевић, Тканине у привреди средюовјековног Дубровника, Српска академија наука и уметности, Београд 1982, стр. 34.

35 [...]"da se zaključiti da bi ovaj lokalitet trebalo tražiti u blizini Cernice, Gacka i Ključa, te, u pretpostavci povezati sa današnjim uzvišenjem koje se i danas tako naziva (Kameno brdo), a smještenom upravo pored Ključa i Cernice" [...]. Esad Kurtović, Monte Lapidoso - Kameno brdo, y: Срђан Рудић (прир.), Споменица академика Симе Ћирковића, Историјски институт, Београд 2011, стр. 206.

36 Radovin Qualchouich [...]conqueritur contra Veselchus Radimillouich dicens quod Veselcho accepit unum ensem valorem yperperos octo in Cameno berdo [...]. DADU, Lam de for. sv. 2, f. 41v (25. III 1411). 
pomenuti Grubač sa svojim ljudima. Oduzeo im je jedan dukat, dva groša i trgovačko pismo. ${ }^{37}$

U Cernici je opljačkan i Budisav Bogavčić, koji je optužio Miroslava Bračića i Radmila Terka, navodeći da su mu oduzeli jedan tovar brašna (unam salmam farine) i 15 perpera. ${ }^{38}$

Septembra 1412. godine Brajko Medojević optužio je Radoslava Pribičića i Vukosava Pribinjića iz Cernice da su sa družinom napali pratnju dubrovačkog kancelara Jakova koji je preko Gacka putovao za Ugarsku. Brajko je naveo da su mu tom prilikom otuđene stvari u vrijednosti od 15 perpera. ${ }^{39}$

Dana 5. jula 1414. godine Ljubiša Veselković optužio je trojicu razbojnika da su ga opljačkali u Gacku, u polju. ${ }^{40}$

U Cernici su maja 1428. godine predmetom otimačine bile tkanine, sklavine i fustan. ${ }^{41}$ Tri mjeseca kasnije ponovo se pominje Cernica kao mjesto razbojništva. ${ }^{42}$

Navedeni prestupi su počinjeni u vrijeme kada je ovim područjem vladao vojvoda Sandalj Hranić. Brojne pljačke i razbojništva počinjeni su na ovom području i u doba uprave Sandaljevog nasljednika hercega Stefana Vukčića Kosače. Na osnovu tužbe Radonje Mikovića saznajemo da su maja 1443. godine u jednom napadu i otimačini učestvovala sedmorica Cerničana koji su pretukli i opljačkali Vukšu Divičića. ${ }^{43}$

37 DADU, Lam de for. sv. 2, f. 44v (15. IV 1411).

38 Budislauus Bogaucich coram domino Marino de Bucignole Rectore conqueritur contra Miroslauum Brecich et contra Radmilum Tercha [...]. DADU, Lam de for. sv. 3, f. 5r (27. VIII 1412).

39 DADU, Lam de for. sv. 3, f. 10v; Н. Мандић, Српске породице војводства Светог Саве, стр. 175.

40 Glubissa Veselchouich coram domino Michaele de Resti conqueruntur contra Stracinum Volchoslaglich, Rugia Bogoslaglich, Lucam eius filio [...]. DADU, Lam de for. sv. 3, f.143v (5. VII 1414).

41 DADU, Lam de for. sv. 8, f. 19r (11. V 1428); Д. Ковачевић-Којић, Градска насеља, стр. 196.

42 DADU, Lam de for. VIII, f. 58 (6. VIII 1428).

43 Pavo Žıvković, Ekonomsko-socijalne promjene u bosanskom društvu u XIV iXV stoljeću (Utjecaj primorskih gradova na ekonomsko-socijalne promjene u bosanskom društvu u 14. i 15. stoljeću - Pojava građanske klase i novog plemstva), Univerzal, Biblioteka Istorija i revolucija, Tuzla 1986, str. 147, nap. 29; Б. Храбак, Из старије прошлости Босне и Хериеговине, књ. IV, стр. 71. 
U pljačkama i otimačini učestvovali su i ugledni Cerničani, oni koji su trebali da štite i provode zakone. Svakako, među najuglednijim Cerničanima svojevremeno je bio knez Dobrovuk Ratković. ${ }^{44}$ Septembra 1436. godine Dabiživ Budaković i Gruban Božiković optužili su: Dobrovuka Ratkovića kneza Cernice, Bogdana Klapčića, Ivana njegovog brata, Vukosava, Dobrašina i Gojaka Radašinića, braću Radoja Pripičića i Ratka Pripičića, Radoja Brajanovića, Pribinju Golubića, Radonju Bogišića i njegovog oca Bogišu i na kraju Grubana Branilovića. Navedeni su optuženi da su ukrali konja, jedan mač, jednog škopca, 100 libri voska i novac. ${ }^{45}$ Nešto kasnije, zbog pljačke jednog konja, pred dubrovačkim knezom optužen je Vukac Miogodović iz Cernice. Tužbu je podigao Vukota Gojtanović (Vochota Goytanouigh). ${ }^{46}$ Nepune četiri godine kasnije, navedeni Vukac Miogodović iz Cernice je, zajedno sa jednim dubrovačkim mesarom, pozajmio od Petra Pucića 73 perpera na rok otplate od mjesec dana. ${ }^{47}$ Septembra 1442. godine u Dubrovniku je podignuta optužnica protiv Radana Tvrdisalića zbog pljačke voska u Cernici. ${ }^{48}$

Oktobra 1442. godine, nemio događaj na putu od Cernice do Kamenog brda, doživio je Nikola Jonović majstor za pravljenje pojaseva, kojem je Radoje Višić iz Cernice ukrao 16 libri voska, o čemu je svjedočio Cvjetko pojasar. Mjesec i po dana kasnije, Cvjetko Nikolić, takođe majstor za pravljenje pojaseva, najvjerovatnije ranije pomenuti svjedok, takođe je opljačkan u Kamenom brdu od strane Bratulja Miokanovića. Otuđena mu je izvjesna količina voska i druga roba. ${ }^{49} \mathrm{U}$ istom periodu je optužen i Pribin Brajčević da je učestvovao

44 МихаилоДинић, Хумско-требинска властела, Посебна издања. Књ. CCCXCVII, Одељење друштвених наука, књ. 54, Научно дело, Српска академија нука и уметности, Београд 1967, стр. 79; Д. Ковачевић-Којић, Градска насель а, стр. 176, 235.

45 DADU, Lam de for. sv. 11, f. 189v (4. IX 1436).

46 DADU, Lam de for. sv. 12, f. 33r (25. V 1438).

47 Nos Milien Plesich becharius et Vochaz Miogodouich de Zrniza conifitemur quod super nos et omnia bona nos dare et soluer Petro Ni. de Poza yperperos septuaginta tres usque ad unum mensem [...]. DADU, Deb. Not. sv. 21, f. 162v (24. IX 1442); Н. Мандић, Српске породице војводства Светог Саве, стр. 347.

48 DADU, Lam de for. sv. 16, f. 14r; Н. Мандић, Српске породице војводства Светог Саве, стр. 347.

49 DADU, Lam de for. sv. 16, f. 46v (27. X 1442); f. 64v (10. XII 1442); P. Žıvкоvić, Ekonomsko-socijalne promjene u bosanskom društvu u XIV i XV stoljeću, 
u otimačini četiri kupela pšenice koja su bila upućena iz Cernice u Dubrovnik. ${ }^{50}$

Novembra 1442. godine u Cernici je zaplijenjeno skupocjeno srebro koje je iz Novog Brda prevoženo u Dubrovnik. Najvjerovatnije po nalogu Stefana Vukčića, njegov knez Vukman Jugović zaplijenio je srebro i zlatnike Dubrovčaninu Milobratu Radosaliću a njega stavio u okove. ${ }^{51}$

Istaknuta D. Kovačević - Kojić, analizirajući mnoge prepiske i intervencije, ranije je konstatovala da je najveći pljačkaš među bosanskim feudalnim vlastelinima bio Stefan Vukčić, od koga je često zahtijevano da vrati oduzetu robu, najčešće srebro. ${ }^{52}$

Maja 1443. godine, kurir Pulko Branković imao je nalog da ode u Cernicu, međutim, tokom putovanja presretnut je u mjestu Skrobotnu i napadnut od strane Ljubiše, Novaka i Vukašina Milišića i Radonje Milančića. ${ }^{53}$

Nisu pljačkani samo trgovci koji su bili u tranzitu već su se pljačke i otimačine dešavale i među susjedima okolnih naselja Cernice. Šire područje Rudina pa sve do Trebinja naseljavali su vlasi Plijeske (Pliščići, Pljesčići), kojima su pripadali i vlasi Vragovići (vlachis Vragouichii de Pliesche). ${ }^{54}$ Plijeske su naseljavali i selo Stepen, o čemu svjedoče srednjovjekovni spomenici stećci i natpisi na njima. Odavno je poznato da su u Velikom groblju u selu Stepenu sahranjeni Vuko-

str. 147; Н. Мандић, Српске породице војводства Светог Саве, стр. 347; Б. Храбак, Из старије прошлости Босне и Хериеговине, књ. IV, стр. 71.

50 Б. Храбак, Из старије прошлости Босне и Хериеговине, књ. IV, стр. 71.

51 Д. Ковачевић-Којић, Градска насељь , стр. 93, 257.

52 Desanka Kovačević, Trgovina u srednjovjekovnoj Bosni, Naučno društvo NR Bosne i Hercegovine, Djela, knj. XVIII, Sarajevo 1961, str. 51.

53 Pulcus Brancouigh correrius coram domino Rectore ser Nicola Matei de Georgio facit lamentum supra Gliubissam Milisigh et supra Nouach Milisigh et Vocasinum Milisigh et supra Radognam Milancigh eorum fantum, dicens quod cum ipse Pulcus iret in Cerniçam ipsi quattuor accusati insultauerunt ipsum Pulcu in loco vocato Scrobotno et eum verberauerunt et per vin arripuerunt sibi res infrascriptas, videlicet, octo yperperis in una bursa, unum mantellu, unum capellum [...]. DADU, Lam de for. sv. 16, f. 217r (25. V 1443).

54 DADU, Lam. de for. sv. 41, f. 153v; Михаило Динић, Из Дубровачког архива, књ. III, Српска академија наука и уметности; Научно дело,Београд 1967, стр. 142-143. 
sav Pliščić, knez svih vlaha kralja Raške i Bosne i njegov sin Viganj. ${ }^{55}$ U susjednom selu Koritima nastanio se jedan dio vlaha Maleševaca. Takođe, i u selu Kutima u Cernici bili su naseljeni Maleševci.

Dana 11. oktobra 1443. godine, Nikola sin dubrovačkog mesara Miljena Pliščića, često evidentiranog u izvorima, pošao je sa robom iz Cernice za Dubrovnik. Međutim, u Kamenom brdu napadnut je i pokraden od strane Miloša Starovlaha i Radiča Velimirovića. Ukraden mu je jedan tovar voska, jedan tovar jagnjećih koža, 42 dukata i 153 perpera. ${ }^{56}$

Navedeni pljačkaš Miloš Starovlah, od ranije je poznat u istorijskoj literaturi. Godine 1440. registrovan je da živi u susjednom naselju Korita. ${ }^{57}$

Iz Korita iz katuna Maleševaca bio je pomenuti Radič Velimirović koji je i sljedeće godine zabilježen ponovo u pljački u Cernici. Dana 6. juna 1444. godine Vlakuša Junaković i Marin Ivanov de Ruđa optužili su Radovča Pribetića i Radiča Velimirovića, vlahe Maleševce, da su za njihov račun prevozili devet tovara voska dubrovačke mjere, u čijoj se pratnji nalazio Marinov sluga Đurko Dobrilović. Međutim, navedena dvojica prevoznika su u Cernici prisvojili vosak. O ovom događaju svjedočila su četvorica svjedoka. ${ }^{58}$

55 O navedenim natpisima i vlasima Pliščićima vidi: P. SLIJEPČEvić, "Staro groblje po Gacku", Glasnik Zemaljskog muzeja 40 (2), Sarajevo 1928, str. 62; Marko Vego, Novi i revidirani natpisi iz Hercegovine (nastavak), Glasnik Zemaljskog muzeja (Arheologija) 19, Zemaljski muzej, Sarajevo 1964, str. 32-33; M. Vego, Zbornik srednjovjekovnih natpisa Bosne i Hercegovine, III, str. 58-59; Д. Ковачевић-Којић, Средюовјековни катун по дубровачким изворима, "Симпозијум о средњовјековном катуну", Научно друштво Босне и Херцеговине, Посебна издања 2, Одјељење историјско-филолошких наука 1, Сарајево, 1963, стр. 134; Н. Мандић, Српске породице војводства Светог Саве, стр. 328; Б. Храбак, Из старије прошлости Босне и Хериеговине, књ. V, стр. 241.

56 DADU, Lam de for. XVII, f. 67; Б. Храбак, Из старије прошлости Босне и Хериеговине, књ. IV, стр. 71.

57 Milos Serovlach de Corita [...]. DADU, Deb. Not. sv. 20, f. 92r (16. XI 1440); IGNACIJ Voje, Delež hercegovskih vlahov v kreditni trgovini srednjeveškega Dubrovnika, Zgodovinski časopis, št. 4, Zgodovinsko društvo za Slovenijo Ljubljana 1977, str. 467, nap. 13.

58 Vlacusa Junachouich et Marinus Jo de Rugia coram domino Rectore ser Johanne de Goze facerunt lamentum supra Radouaç Pribitich Maleseuaç, Radiç Velimirouich Maleseuçe morlacos, dicens quod Giurchus Dobrilouich fantus Marini suprascripti acordauit ipsos in Cerniza quod deberent conducere sal- 
Nasljednici Radiča Velimirovića Maleševca bili su Radičevići. Idući tom linijom, najvjerovatnije da su Radiča Maleševca sinovi: Dobrie, Miroslav, Radivoje i Ivan Radičević. Početkom 1453. godine, navedeni Radičevići i još trojica Maleševaca, optuženi su zbog pljačke tkanina, novca i druge robe u Kutima. ${ }^{59}$ Tri godine kasnije, u tužbi koju je podigao Vidak Hervačević iz Konavala kao pljačkaši između ostalih navedeni su dvojica braće, Ivana i Dobrie sinovi vlaha Radiča zvani Maleševci. ${ }^{60}$

Bogumil Hrabak je konstatovao da je Cernica ponekad bila etapna stanica u kojoj su bili nastanjeni karavanski prevoznici čije je osnovno zanimanje bilo ponosnik. Roba upućena iz Dubrovnika ponekad se prevozila do Cernice a zatim je vršen pretovar na tovarne životinje u vlasništvu Cerničana, koji su je potom prevozili do određenih destinacija Bosne ili Srbije. ${ }^{61}$

Najagilniji prevoznici bili su vlasi Maleševci, smješteni na širem području Rudina u: Koritima, Kutima, Malini, Žudojevićima, Vidnjama, Skrobotnu, Dubočanima i Vrbnu. ${ }^{62}$ Istaknute karavandžije svojevremeno bili su braća Hlapac i Stanoje Stanković iz mjesta Kuti. Esad Kurtović je takođe pisao da su navedeni Stankovići živjeli u selu Kutima. Na žalost, potpuno je pogrešno konstatovao da je u pitanju današnje selo Kuti, smješteno na presedlini između Dabarskog i Fatničkog polja. ${ }^{63}$ Selo Kuti nalazilo se u Cernici, što potvrđuju pisani dokumenti. U jednom sudskom procesu koji se odnosi na prevoz tkanina iz Dubrovnika u Srbiju zabilježeno je događaj u mjestu zva-

mas nouem cere Ragusium ipsis Vlacuse et Marino [...] DADU, Lam. de for. sv. 18, f. 3v (6. VI 1444).

59 Matchus Bogossalich cimator coram domino Rectore ser Zupano de Bona lamentatur contra Dobrie Radizeuich, et Mirossavum Radizeuich, et Vuchich Vuchcich, Radiuoi Radizeuich, Iuanum Radizeuich, Radiuoi Balichouich, Balicho Cherachouich dicens quod per viam sibi repuere in Cuti petias decem pani [...]. DADU, Lam de for. sv. 33, f. 31r (19. I 1457).

60 DADU, Lam de for. sv. 33, f. 252' (13. V 1460).

61 Б. Храбак, Из старије прошлости Босне и Херцеговине, књ. IV, стр. 68.

62 Radmilo Pekić, Maleševci in Bileća>s Rudine, Collection of papers of the Falculty of Philosophy, vol. XLVI (3), Kosovska Mitrovica 2016, str. 21-51.

63 Esad Kurtović, "Slavni ljudi svoje vrste - Stankovići vremena vojvode Sandalja Hranića Kosače", U. S. Jerše, D. Mihelič, P. Štih, (pr.) Med srednjo Evropo in Sredozemljem, Vojetov zbornik, Založba ZRC, Ljubljana, str. 402, nap. 47. 
nom Kuti, iznad teritorije kneza Vladislava u Cernici (...in loco dicto Cuti supra teritorio comitis Vladissaui in Cernicam). ${ }^{64}$

Maleševac Stanoje Stanković imao je nalog da preveze 26 tovara tkanina do crkve Sv. Petra na Limu, uz obavezu da prenese robu tačno određenom putnom deonicom ("viam Anagosti aut ad viam Cernize"). Cijena prevoza iznosila je pet perpera po tovaru. ${ }^{65}$

Karavandžijama i vlasnicima robe nije uvijek bilo bezbjedno kretanje na relaciji Dubrovnik - Cernica. Opasnost im je prijetila i od ponosnika iz drugih katuna. U jednoj takvoj situaciji nalazio se pomenuti karavandžija Stanoje Stanković, koji je juna 1425. godine imao nalog da za račun Franka Nikolinog, Boljašina Radatovića i njihovog društva preveze robu od Dubrovnika do Cernice. ${ }^{66}$

Prevoznik iz Cernice bio je Radoslav Dapković koji je februara 1427. godine, na svoj rizik a za račun Luke Sorkočevića, prevezao tri tovara robe do Borča po cijeni sedam perpera za svaku prevezenu balu. Prilikom sklapanja ugovora od Luke je uzeo kaparu u iznosu od devet perpera. ${ }^{67}$

Maleševcima je pripadao i prevoznik iz Skrobotna Baljko Heraković, sin ponosnika Heraka Miloševića, koji je marta 1440. godine po nalogu Mihajla Volčića prevozio tkanine iz Dubrovnika do Cernice. ${ }^{68}$ Brat Baljka Herakovića bio je Vukša Heraković (Vochsam Chierachouich) koji je ranije pljačkao u Malini. ${ }^{69}$

Zanimanje ponosnik od pradjeda Miloša Radanovića, djeda Heraka Miloševića i oca Baljka Herakovića preuzeo je Radivoj Baljkovićc. ${ }^{70}$ Novembra 1464. godine Radivoj Baljković imao je nalog od Andrea

64 DADU, Lam de for. sv. 36, f. 58r (15. XI 1464).

65 Stanoye Stancovich de Malesseuice vlach [...] obligat Brathoslauo Pridoyevich et Anthoye et Braicho Bogoyevich portare viginti sex salmas pannorum[...]. DADU, Div. Canc. sv. 39, f. 295r (16. IX 1413).

66 DADU, Div. Canc. sv. 43, f. 150v (13. VI 1425).

67 Radosauus Dapchouich de Cerniça [...]. DADU, Div. Canc. sv. 44, f. 106v (8. 2 1427).

68 DADU, Div. Not. sv. 24, f. 32v (12. III 1440); Радмило Пекић, Херак Милошевић - крамар Малешеваи, Зборник радова XLVI (1), Филозофски факултет, Косовска Митровица, 2016, стр. 413-414.

69 [...] "in Malini prope Tribignam" [...] DADU, Lam de for. sv. 4, f. 76r (5. IX 1419).

70 DADU, Div. Not. sv. 41, f. 152v (2. V 1457); R. Pekić, Maleševci in Bileća's Rudine, str. 36-38. 
Crijevića, Frančeska Obuganovića, Stjepka Bjeloševića, Ivaniša Miotoševića i Benka Glavaša da oformi karavan i prenese tkanine iz Dubrovnika u Srbiju. ${ }^{71}$

U svojstvu prevoznika, 1442. godine pominju se Milaš Maslešić i Vukša Vlatković iz Cernice, koji su za račun Ivana Tihojevića prevezli tkanine i drugu robu u Podborač (portare sub Boraç) po cijeni od 9,5 perpera za svaku prevezenu balu. ${ }^{72}$

Dvije godine kasnije, Rasko Hrebeljanović Maleševac prevezao je 12 tovara voska iz Cernice, iz mjesta zvanog Ključ, do Dubrovnika, po računu gospođe Dobrule, supruge Ivana Lampre iz Kotora. ${ }^{73}$

Jedan od najuglednijih Cerničana iz prve polovine XV vijeka bio je Vučeta Radmilović, koji je izvjestan period obavljao funkciju kneza Cernice. Zbog obima poslovanja smatra se jednim od najvećih trgovaca iz Cernice svoga doba. ${ }^{74}$

Iako je trebalo da provodi zakonitosti, Vučeta se pominje kao učesnik u pljačkama i otimačinama. Dana 9. maja 1443. godine Radonja Mirković je, u svojstvu zastupnika Vukše Đuričića, pred dubrovačkim knezom optužio Vučetu Radmilovića, Brajulina Bogčića, Radovana Tvrdisalića, Vukšu Vlatkovića, Milisava Petrovića, Radoju Tikosaljića i Radoja Radišića, da su navedeni opljačkali tkanine i novac Vukši Đuričiću u Cernici. ${ }^{75}$

Na području Cernice i Kamenog brda u otimačini su se istakli i vlasi Banjani koji su opljačkali Radina Bogosalića, dok su vlasi Pilatovci,

71 DADU, Lam de for. sv. 36, f. 58r (15. XI 1464).

72 Milas Maslesich et Vuxa Vlatchouich de Cerniza [...]. DADU, Div. Not. sv. 9, f. 240r (20. II 1435); Upor: P. Žıvković, Ekonomsko socijalne promjene u bosanskom društvu u XIV i XV stoljeću, str. 147.

73 DADU, Div. Canc. sv. 58, f. 203r (24. II 1444).

74 DADU, Lam de for. sv 4, f. 140r (29. I 1420); Deb. Not. sv. 14, f. 79v (20. XII 1426); f. 368v (23. XII 1429); sv. 48,f. 152v (9. I 1448); f. 153v (10. I 1448); f. 155v (12. I 1448); Div. Not. sv. 31, f. 26r (3. III 1446); f. 26r (4. III 1446); f. 130r (5. IX 1446); f. 132v (8. X 1446); Д. Ковачевић-Којић, Градски живот у Србији и Босни (XIV-XV вијек), Историјски институт, Београд 2007, стр. 284.

75 Radogna Mircouigh tanquam procurator Vuxe Giuricigh coram domino Rectore Ser Nicola Matei de Georgio facit lamentum supra Vucettam Radmilouigh et Braiulinum Boghcigh, Radouanum Tuerdisaligh, Vuxam Vlatcouigh, Milissau Petrouigh, Radoe Ticosaligh, et Radoe Radisigh [...]. DADU, Lam de for. sv. 16, f. 200v. 
naseljeni na području Bileće, opljačkali Budeča Petkovića. Od iste skupine vlaha, nešto kasnije, na istom mjestu je pokraden i Radoje Radulinović. Između ostalog ukraden mu je vosak i četiri lisičje kože. Pored navedenih, u Kamenom brdu presretali su i otimali robu vlasi Dobričići i vlasi Prijeraci. ${ }^{76}$

Tokom treće decenije XV vijeka a i kasnije, po obrtnom kapitalu izdvajaju se od ostalih Cerničana, Ostoja i Vukota Dabižinović. Poslovni partneri Ostoje Dabižinovića bili su: Ivan Prodanelić, Antonije Butko i Nikola Brajković. ${ }^{77}$ Međutim, tokom četrdesetih godina XV vijeka i Ostoja Dabižinović iz Cernice pominje se kao pljačkaš. ${ }^{78} \mathrm{U}$ istom periodu dvojica braće iz Cernice i jedan njihov kompanjon pokrali su trojicu trgovaca, koji su podigli tužbu 19. avgusta 1446. godine. ${ }^{79}$

Pored Vukote i Ostoje, u pljačkama je učestvovao i Stjepko Dabižinović iz Cernice. Dana 19. januara 1457. godine Milisava Obradova optužila je Stjepka Dabižinovića, zvanog Tupačić iz Cernice, da je ukrao jedan kupel žita i druge stvari. ${ }^{80} \mathrm{O}$ ovom događaju svjedočili su, Radoslav Radovčić i Brajo, češljar vune. Međutim, sudski proces se otegao. Jedan od svjedoka, Radoslav Radovčić, svjedočio je pred dubrovačkim knezom Sigismundom Gučetićem tek 12. oktobra 1457. godine. On je izjavio da je navedeni Stjepko od rečene Milisa-

76 DADU, Lam de for. sv. 4, f. 103v (5. XI 1419); sv. 19, f. 69r (2. V 1445); f. 117r (27. VI 1445); f. 286r (30. XI 1445); sv. 36, f. 84r (15. XII 1464); E. KurTović, Monte Lapidoso - Kameno brdo, str. 198-200.

77 P. Žıvković, Ekonomsko-socijalne promjene u bosanskom društvu u XIV $i$ XV stoljeću, str.146.

78 Radic et Vuxa Grubaceuichi, fratres, coram domino Rectore ser Georgio de Goze fecerunt lamentum supra Ostoiam Dabisinouich mostachi, Radognam et Vochich Pribisalichi, fratres dicentes quod acceperunt arrepto sibi per vim unum equum cum sela, unum ensem, arcum fulcitum cum friciis unum talabachum ducatos XXV in moneta, unam capsam plenam vitris pro fenestris quam mittebat ser Damianus de Sorgo domino despoto et dixerunt suprascripti: voioda Stiepan ligat te et facit tibi facere istud, et hoc fuit apud Zerniza in contrada voivode Stiepani. DADU, Lam de for. sv. 20, f. 144v (4. VII 1446); Верена Хан, Архивска грађа о стаклу и стакларству у Дубровнику (XIVXVI век), Балканолошки институт, САНУ, Београд 1979, стр. 75-76.

79 DADU, Lam de for. sv. 20, f. 181v (19. VIII 1446).

80 Milisaua Obradoua coram domino Rectore Ser Zupano de Bona lamentatur contra Stepchum Dabisinouich dictum Tupazich de Cerniza[...] unum mantelum de raxa, 4 petias rassi, librare 40, unum barchanum et unum cupelum grani [...]. DADU, Lam de for. sv. 30, f. 32v (19. I 1457). 
ve, u mjestu zvanom Kameno brdo, oduzeo mantil rašni, i iz jednih bisaga stvari. ${ }^{81}$

Cerničani su zadavali neprilike i Vukiću Radovanoviću, 1456. godine. On je u optužnici naveo da ga je opljačkao Bratić i njegova majka Rodna, oboje iz Cernice. Ukrali su mu 20 perpera, dva groša i jednu torbicu zlatnu. ${ }^{82}$

Sa nasiljem i otimačinom nastavljeno je i u periodu osmanlijske uprave. Vlasi su hvatali, prodavali i preprodavali ljude međusobno ili Turcima Osmanlijama u Cernici.

U dubrovačkim izvorima pominju se brojni Tasovčići iz Gacka i Cernice. Neki od njih odselili su u Dubrovnik i tamo ostali trajno. ${ }^{83} \mathrm{Je}-$ dan od njih bio je zanatlija Milić Tasovčić, koji je optužio svoga zeta Raduna Milićievića, vlaha Maleševca nastanjenog u selu Koritima, da je njegovu sestru a svoju ženu Ljubisavu - prodao Turcima za devet dukata. Mjesec dana kasnije, Radič Božidarović iz Gacka, koji se naselio u Dubrovnik, optužio je Petka Budisaljića iz Župe Dubrovačke da je uhvatio njegovog sina Ratka i prodao Marku, sinu Miloša zvanom Uhoda iz Banjana. ${ }^{84}$

Jedan stanovnik Mlina uhvaćen je i prodat za osam dukata, da bi zatim u Cernici bio preprodat za uvećanu cijenu i to za 20 dukata. Dvije godine kasnije, optuženo je 12 vlaha Žurovića da su uhvatili Dančula Bogdanovića, odveli ga u Gacko u Cernicu i prodali Turčinu Ismailu (Smaju). Nešto kasnije je i Radibrat Rašković krojač optužio Vukotu Cincića iz Gacka da je prodao njegovu sestru Radenku i njeno dvoje djece Turčinu Ismailu u Cernici. ${ }^{85}$

Zahvaljujući prirodnim uslovima koje je pružalo Cerničko i Gatačko polje u tom kraju je bilo razvijeno stočarstvo i pčelarstvo, te se stoga Cerničani pominju i u vezi pljačke i prodaje stoke i stočarskih proizvoda, ali i voska i drugih artikala. Analizom izvora je utvrđeno da je u

81 DADU, Lam de for. sv. 30, f. 32v (12. X 1457).

82 Vuchich Radouanouich coram domino Rectore ser Nicola Ma. de Caboga lamentatur contra Bratich et matrem eius Rodna [...] DADU, Lam de for. sv. 32, f. $77 \mathrm{v}$ (5. VI 1456).

83 DADU, Tes. Not. sv. 13, f. 7r-7v; Радмило Пекић, Становништво Гацка на раду у Дубровнику (XIV-XV вијек), Зборник радова XLVII (2), Филозофски факултет, Косовска Митровица 2016, стр. 302.

84 М. Динић, Из Дубровачког архива, књ. III, стр. 137.

85 М. Динић, Из Дубровачког архива, књ. III, стр. 142-143, 150-152. 
Cernici bila važna stočna pijaca odakle je stoka izvožena u Dubrovnik. U doba uprave Kosača izvjestan dio Cerničana poslovao je u Dubrovniku, ali su istovremeno i Dubrovčani poslovali u Cernici. Septembra 1387. godine, na javnom mjestu u Dubrovniku, Neleško Radoslalić, stanovnik Cernice, prodao je jednog vola crvenkaste boje Bogoslavu Mildrašiću, čovjeku Jakova Gundulića, po cijeni od devet perpera. ${ }^{86}$

Cerničani koji su održavali poslovne veze s Dubrovčanima i uživali njihovo poslovno povjerenje, najčešće su kreditno poslovali. Kreditni zajmovi Cerničana, mahom su se odnosili na neplaćenu robu. Iako je vrijednost u zadužnicama bivala iskazivana u dukatima i perperima, oni su se obično oduživali liferacijom druge robe, one koju su Dubrovčani uvozili. Ponekad su zabilježene obavezne isporuke sitne stoke za novac koji je bio primljen unaprijed. Utvrđeno je da ima dosta primjera gdje su Dubrovčani bili dužni Cerničanima, a radilo se o isporuci stoke na odloženo plaćanje. Pored navedenih oblika kreditnog poslovanja, primjenjivana je i trampa. U Cernici je evidentiran i dubrovački zanatlija koji je donio tkanine da ih zamijeni za stoku. ${ }^{87}$

U pogledu ukupne kreditne trgovine Cerničana u Dubrovniku, Ignacij Voje je konstatovao da se najaktivniji saobraćaj, od svih mjesta u Hercegovini, odvijao između Dubrovnika i Cernice i da su se, u poređenju sa mještanima iz drugih hercegovačkih naselja, najviše u Dubrovniku zaduživali Cerničani. Tako je od 1429. do 1449. godine registrovao 26 dužnika iz Cernice, dok je u drugoj polovini XV vijeka, odnosno u periodu od 1470. do 1500. registrovao 249 kreditnih ugovora koji se odnose na Cerničane. ${ }^{88}$

Međutim, posmatrajući samo period do dolaska Turaka, D. Kovačević-Kojić a potom i B. Hrabak istakli su da se u kreditnim knjigama Cerničani tek pojavljuju od 1426. godine i da njihovo kreditno poslovanje nije bilo većih razmjera. Za razliku od trgovaca iz Prače i Olova, zaduženja Cerničana na godišnjem nivou nijesu prelazila 1.000 dukata. Za period od 1400. do 1463. godine, izračunato je da su Cer-

86 Neleschus Radoslalich habitator di Cerniça facit manifestum quod ipse vendit unum bouem pilli rubei Bogoslauo Mildrasich homo ser Jacob de Gondola ad carum ut moris est pro yperperis VIIII [...]. DADU, Div. Canc. sv. 27, f. 33v (15. IX 1387).

87 Б. Храбак, Из старије прошлости Босне и Хериеговине, књ. IV, стр. 68, $70,75,79$.

88 Ignacij Voje, Kreditna trgovina u srednjovjekovnom Dubrovniku, Akademija nauka i umjetnosti Bosne i Hercegovine, Sarajevo 1976, str. 241, 254. 
ničani evidentirani u 66 zadužnica i da je njihovo ukupno kreditno poslovanje iznosilo 903 dukata i 4.189 perpera. ${ }^{89}$

Između ostalih, u Dubrovniku su kreditno poslovali: Mirko, Vukosav i Radivoj Pribinjić, Vlatko Isaković, Vukac Miokanović, Radan Tvrdisalić, Vuk Radosalić, Milorad Radonjić, Vitko i Ratko Tasovčić i mnogi drugi. U kreditnim knjigama Dubrovačkog arhiva evidentirani su 1426. godine sledeći trgovci iz Cernice: Ostoja, Stefan i Radoja Dabižinović, Vuk Bogčić i Mirko Pribinjić, a početkom januara 1427. godine Dobrivoje Ratković i njegov brat. Takođe, krajem 20-tih i tokom 30-tih godina XV vijeka kreditno su poslovali Vučina Radomanić, Vučeta Radmilović, Radoslav Poznanović, Savo Baldovinić i Mirko Pribinjić. Kasnije je, kao dužnik, evidentiran i Radašin Ostojić. ${ }^{90}$

Tri godine iza pomenutog Radašina evidentiran je i Radonja Vučetić, koji je od dvojice Dubrovčana pozajmio 21 dukat na rok od tri mjeseca. ${ }^{91}$

Ranije pominjani Vukac Bogčić, moguće da je ista osoba registrovana u nešto drugačijoj formi, kao Vukša Bogčinović iz Gacka koji uzima stoku na čuvanje. ${ }^{92}$ Dva mjeseca kasnije, Vukac Bogčić, zajedno sa svojim rođakom Branilom, opljačkao je u Cernici Radoslava Dormitora i njegovog brata Radonju mesara. ${ }^{93}$

Kada je riječ o Vukčevom rođaku najvjerovatnija je pretpostavka da se radi o ranije pominjanom Brajulinu Bogčiću koji je pljačkao zajedno sa Vučetom Radmilovićem. Brajulin Bogčić je bio u Dubrovniku

89 Д. Ковачевић-Којић, Градска насела средњовјековне босанске државе, стр. 173; Б. Храбак, Из старије прошлости Босне и Хериеговине, књ. IV, cтр. 69-70, 82 .

90 DADU, Deb. Not. sv. 14, f. 2r (15. II 1426); f. 11r (21. III 1426); f. 89v (29. I 1427); f. 242v (7. XII 1428); f. 368v (23. XII 1428); sv. 15, f. 175r (5. III 1432); Н. Мандић, Српске породиие војводства Светог Саве, стр. 160, 291, 333, 335-336; Ego Voçina Radomanich de Zerniza confiteor quod super me et omnia mea bona obligo me ("dare et soluere", precrtano) tanquam principale, et ego Radosauus Possnanouich tanquam eius Vuzine plegius confiteor quod super me et omnia mea bona obligo me dare et soluere Ratcho Bogdani Grand yperperos viginta sex et grossos sex usque ad duos mensis proxime futuros [...]. DADU, Deb. Not. sv. 14, f. 374v (24. I 1430).

91 Ego Radogna Vocetich de Zerniza confiteor quod super nos et mnia mea bona obligo me dare et soluere ser Benedeto de Gondola et ser Orsato Mart. de Zamagne ducatos auri viginti unum usqe ad tres mensis proxime futuros [...]. DADU, Deb. Not. sv. 17, f. 73r (11. III 1435).

92 DADU, Div. Canc. sv. 49, f. 223r (15. II 1436).

93 DADU, Lam de for. sv. 11, f. 79v (1. IV 1436). 
27. oktobra 1441. godine i tada je na kredit dobio 192 perpera i 11 groša od Bernarda Gundulića. ${ }^{94}$ Pet godina kasnije, Brajulin Bogčić iz Cernice je ponovo registrovan u kreditnim knjigama. Tom prilikom je poslovao sa dubrovačkim kožarom Radonjom Marojevićem, kod kojega se zadužio 40 perpera. ${ }^{95}$

Radoslav zvani Dormitor nosio je očevo prezime Tvrdisalić. Za njega je u literaturi konstatovano da je iz Trebinja. ${ }^{96} \mathrm{U}$ istom periodu je Tvrdisalića bilo i u Foči. Jedan od njih poslovao je sa dubrovačkim suknarom Galeacom Brunjolom iz Mantove. ${ }^{97}$ Međutim, u dokumentima se konstatuje da je Radoslav Tvrdisalić zvani Dormitor nastanjen u Cernici ali i Dubrovniku. Takođe i njegova braća Radan i Radoslav u dubrovačkim izvorima navedeni su kao Cerničani. Trgovali su stokom, a izvorno su registrovani kao mesari. O njihovoj poslovnoj aktivnosti sačuvani su brojni dokumenti. Radoslav Tvrdisalić zvani Dormitor poslovao je sa braćom, u sopstvenoj režiji a ponekad udružen i sa drugim trgovcima, poput Boška Miobratovića, Božidara Radoslalića zvanog Golišić i Stjepka Stracinovića. ${ }^{98}$ Braća Tvrdisalići takođe su bili žrtve pljačke, ali su, ponekad, zabilježeni i u ulozi pljačkaša. Septembra 1442. godine u Dubrovniku je podignuta optužnica protiv Radana Tvrdisalića zbog pljačke voska u Cernici. ${ }^{99}$ Kasnije je isti Radan Tvrdisalić, brat Radoslava Dormitora (Radanus Tverdisalich frate Radossaua Dormitor) u Dubrovniku dobio na poček 150 perpera od jednog dubrovačkog vlastelina. ${ }^{100}$

Radoslav Tvrdisalić, njegov brat Radonja i Stefan Gojković iz Cernice poslovali su i sa Petrom de Nassis (Našić) iz Zadra. Od pomenutog Zadranina su na poček dobili 140 perpera s rokom otplate kredita

94 Brayulin Bogcich de Cerniza [...]. DADU, Deb. Not. sv. 21, f. 35v (27. X 1441).

95 Braiulinus Bogcich de Zerniza confiteor quod super me et omnia mea bona obligo me dare et soluere Radogna Maroeuich pelipario yperperos quadraginta [...]. DADU, Div. Not. sv. 31, f. 15r (4. II 1446).

96 Д. Ковачевић-Којић, Градска насела средновјековне босанске државе, стр. 176.

97 DADU, Div. Not. sv. 31, f. 14v (1. II 1446).

98 Nos Bosigchus Miobratouich, Bossidar Radosalich dictus Golosich, Stiepchus Stracinouich et Radossauus Tuerdisalich dictus Dormitor[...]. DADU, Deb. Not. sv. 19, f. 38r (6. VI 1439).

99 DADU, Lam de for. sv. 16, f. 14r (20. IX 1442).

100 DADU, Div. Not. sv. 31, f. 59r (6. V 1446). 
od mjesec dana. ${ }^{101}$ Petar de Nassis bio je sin istaknutog Zadranina Damjana Bivalda Nassisa. ${ }^{102}$

U jednom kreditnom ugovoru koji su sklopili Radoslav Tvrdisalić i Stefan Gojković sa Martinom Luke Sorkočevićem, za Radoslava Dormitora je navedeno da je iz Dubrovnika, dok je za Stefana Gojkovića, ranije evidentiranog da je iz Cernice, tom prilikom konstatovano da je iz Viševa i da je čovjek vojvode Stefana. ${ }^{103}$

Dana 5. oktobra 1446. godine Radoslav Dormitor mesar i Dobrovoj iz Gacka zadužili su se kod Marina Menčetića na iznos od 37 dukata zlatnih, na rok otplate od mjesec dana. ${ }^{104}$ Narednog dana je Radoslav Tvrdisalić sklopio još jedan kreditni ugovor. Zajedno sa Miloradom Radonjićem iz Cernice od Simona Bunića dobili su na poček 172 perpera, 11 groša i osam parvula, $s$ rokom otplate od mjesec dana. ${ }^{105}$ Idućeg dana Radoslav je u sopstvenoj režiji sklopio još jedan kreditni ugovor i to sa Benkom Kotruljevićem koji ga je kreditirao sa vrijednošću od 21 dukata na period od dva mjeseca. ${ }^{106}$

Kreditnom trgovinom tokom 40-tih godina XV vijeka poslovali su i Cerničani: Brajko Terzić, ${ }^{107}$ Vuk Radosalić i Radoslav Radovčić zvani Raspačić. Njihov vjerovnik bio je Dobrie Raspačić. ${ }^{108}$ Kasnije se Vuku

101 DADU, Div. Not. sv. 31, f. 15r (4. II 1446).

102 Serøo Dokoza, Damjan Bivaldov Nassi (oko 1338. - 1408.), Radovi Zavoda za povijesne znanosti HAZU u Zadru, sv. 57, Hrvatska akademija znanosti i umjetnosti, Zadar 2015, str. 108, 111, 130-131, 139.

103 Nos Radossavus Turedissalich Dormitor de Ragusi et Stipanus Goychouich de Vissevo homo voyvode Stephan [...]. DADU, Div. Not. sv. 31, f. 151v (9. XI 1446).

104 Nos Radossauus Dormitor becarius et Dobrovoi Gazcho [...]. DADU, Div. Not. sv. 31, f. 130v (5. X 1446).

105 Nos Radan Tuerdisalich et Milorad Radognich de Zerniza[...]. DADU, Div. Not. sv. 31, f. 132r (6. X 1446).

106 Ego Radossavus Turedissalich dicti Dormitor [...] dare et soluere Ser Benedeto de Cotrullio ducatos auri viginti quatuor [...]. DADU, Div. Not. sv. 31, f. 150r (7. XI 1446).

107 Ego Braychus Tersich de Zerniza confiteor quod super nos et omnia mea bona obligo me dare et soluere Ser Benedeto de Gondola ypp. centum viginti quatuor et gross. septem usqe ad unum mensem proxime futuros [...]. DADU, Deb. Not. sv. 21, f. 65r (5. I 1442).

108 Nos Voch Radosalich de Cerniza et Radossauus Raspacich confitemur quod super nos et omnia nostra bona obligo me dare et soluere Dobrie Raspacich ducatos auri centum quinquaginta sex [...]. DADU, Div. Not. sv. 31, f. 99v (20. VII 1446). 
Radosaliću i Radoslavu Radovčiću pridružio i izvjesni Cvjetko, te su od prethodno pomenutog vjerovnika pozajmili 215 perpera. ${ }^{109}$

Za razliku od navedenih, rijetki su kreditni ugovori u kojima participiraju Cerničani a da vrijednost kredita prelazi 100 dukata. Od Cerničana to je bilo svojstveno Vučeti Radmiloviću za kojeg su raniji istraživači konstatovali da je bio trgovac u pravom smislu te riječi. Poslovni partneri Vučete Radmilovića, između ostalih, bili su: Ivan Gundulić, Ivan Živolinović, Ilija Restić, Benko Gundulić i drugi. ${ }^{110}$

Krajem četrdesetih godina XV vijeka u kreditnim knjigama Dubrovačkog arhiva zabilježena su dva brata iz Cernice, Obrad i Milorad Radonjić, ljudi vojvode Stefana i Živan Pierović, berberin u Cernici. Braća Radonjići podigli su kredit od izvjesnog Ratka u vrijednosti od 18 zlatnih dukata s rokom otplate o mjesec dana, dok je pomenuti Živan pozajmio 13 zlatnih dukata od suknara Radosava Radonjića. ${ }^{11}$

U drugoj polovini XV vijeka između ostalih pominje se i Petar Vukosalić iz Cernice. ${ }^{112}$ Septembra 1463. godine Božiko Mozglić iz Cernice kreditno je poslovao sa obućarom Radonjom Bogosalićem. Vrijednost pozajmice iznosila je 15 dukata. ${ }^{113}$

Sredinom 60-tih godina u Dubrovniku je kreditno poslovao i Miroslav Milojković iz Cernice koji je pozajmio od Vukše Radakovića 23 perpera. ${ }^{114}$

Cerničani su održavali poslovne veze i sa trgovcima iz raznih mjesta, ponekad se i udruživali sa njima. Neki od Cerničana, poput Radiča Tvrdisalića i Radiča Milobratovića poslovali su u Foči i Prači. Intezivne poslovne veze Radič Milobratović imao je i sa Dubrovčanima

109 Nos Vuoch Radosalich de Cerniza et Cuetcho Dobrouocheuich et Radossauus Radoucich dictius Raspacich [...]. DADU, Div. Not. sv. 31, f. 156v (23. XI 1446).

110 DADU, Div. Not. sv. 31, f. 26r (3. III 1446); f. 26v (4. III 1466); f. 130v (5. X 1446); f. 132v (8. X 1446).

111 Nos Hobrad et Milorad fretres Radognich de Zerniza [...]. DADU, Deb. Not. sv. 24, f. 13v (27. V 1448); sv. 25, f. 1v (16. VI 1449); Н. Мандић, Српске породице војводства Светог Саве, стр. 335, 353.

112 DADU, Deb. Not. sv. 33, f. 23r (5. V 1458).

113 Bosigchus Mosgalich de Cerniza [...]. DADU, Deb. Not. sv. 36, f. 25v (26. IX 1463).

114 DADU, Deb. Not. sv. 37, f. 23r (5. VI 1465). 
koji su se bavili proizvodnjom i prodajom tkanina. ${ }^{115} \mathrm{Na}$ Radiča Milobratovića pažnju su skrenuli I. Voje, M. Vego i B. Hrabak. ${ }^{116}$ Kreditna aktivnost Radiča Milobratovića prelazi vremenske okvire našega rada, međutim značajno je istaći da je nedavno E. Kurtović publikovao rad: "Radič Miobratović, mercator de Cerniza (1467-1506)". Na žalost, u njemu su iznesene brojne netačne tvrdnje, tako da je rad ne upotrebljiv. Između ostalog, autor je na osnovu 51 kreditnog ugovora zaključio da se Radič uvijek zadužuje sam, izuzev jednog ugovora iz 1498. godine. ${ }^{117}$ Da nijesu konstatacije E. Kurtović pouzdane, između ostalog, svjedoči samo jedan kreditni ugovor koji nije uzet u razmatranje, pa je samim tim netačno prikazano i ukupno kreditno poslovanje Radiča Milobratovića. Krajem aprila 1470. godine Radič Milobratović i Vuk Balićijević iz Foče uzeli su na kredit vrijednosti 100 dukata, od suknara Bratuta Gradojevića. ${ }^{18}$

Kakav je trgovac bio Radič Milobratović svjedoči i činjenica da je u kratkom vremenskom roku isporučivo dubrovačkim mesarima od 300 do 400 komada sitne stoke. ${ }^{119}$

U kasnijem periodu, u drugoj polovini XV vijeka, u kreditnim knjigama koje se čuvaju u Državnom arhivu u Dubrovniku pominje se na desetina Cerničana, između ostalih: Radašin Utješanović, Ljubiša Dinčić, Ratko i Radelja Brajković, Radan Obradović, Vladoje Radmilović, Radič Dobrašinović, Radoje Milobratović, Cvjetko Stančić, Đurađ Radojković, Obrad Radosalić, i mnogi drugi. Međutim, zbog hronološkog ograničenja rada, koji obuhvata period do pada Cernice

115 Радмило Пекић, Дубровачка антунинска $n$ ородица Градојевић Братутовић, поријеклом из Требиюа, Зборник радова XLVI (4), Филозофски факултет, Косовска Митровица, 2016, стр. 184-185.

116 Ignacij Voje, Kreditna trgovina u srednjovjekovnom Dubrovniku, Akademija nauka i umjetnosti Bosne i Hercegovine, Sarajevo 1976, str. 254, nap. 230; I. VoJe, Poslovna uspešnost trgovcev v srednjeveškem Dubrovniku, Znanstveni inštitut Filozofske fakultete, Ljubljana, 2003, str. 255; MARKo VEGo, Ispisi iz Historijskog arhiva u Dubrovniku o srednjovjekovnoj Hercegovini, Hercegovina 1, Muzej Hercegovine, Mostar 1981, str. 306, 310, 311; Б. Храбак, Из старије прошлости Босне и Хериеговине, књ. IV, стр. 72.

117 Esad Kurtović, Radič Miobratović, mercator de Cerniza: (1467-1506), Godišnjak BZK Preporod XII, BZK "Preporod", Sarajevo 2012, str. 298.

118 Nos Radiz Milobratouich de Cerniza et Vuch Baglichieuich de Choza confiteor quod super me et omnia mea bona obligo me dare et soluere Bratuto Gradoeuich ducatos auri centum [...]. DADU, Deb. Not. sv. 38, f. 181v (30. IV 1470).

119 DADU, Deb. Not. sv. 42, f. 17r (24. VIII 1473). 
pod vlast Osmanlija, kreditnoj trgovini Cerničana posvetili smo posebnu pažnju u drugom radu predatom u štampu.

U Cernici je postojao i izvjestan broj trgovačkih radnji, čiji su vlasnici bili domaći trgovci kao i privremeno nastanjeni Dubrovčani. Zabilježeno je i da je iz jednog lokala iz Cernice ukradeno 30 libri voska. $\mathrm{U}$ istom periodu u Cernici je bio naseljen ("ad presens habitans in Cernica") Radonja Pribisalić, koji je imao svoju trgovačku radnju. ${ }^{120}$

Osam godina kasnije je evidentirano da je Radonja Pribisalić iz Cernice, zajedno sa dvojicom poslovnih partnera, kreditiran od strane poznatog suknara Radiča Grubačevića. Vrijednost kredita iznosila je 44 zlatna dukata. ${ }^{121}$

Kakvu je radnju posedovao u Cernici Radonja Pribisalić, nije nam poznato. Za razliku od njega, kako ističe N. Mandić, Ratko Cvjetković je 1435. godine bio krčmar u Cernici. ${ }^{122}$

Pored trgovaca u doba uprave Kosača u Cernici je zabilježeno i nekoliko zanatlija, gdje posebnu pažnju privlači ranije pominjani Cvetko Nikolić, majstor za pravljenje pojaseva. ${ }^{123}$

Iz Cernice i Ključa mlada populacija je odlazila u Dubrovnik da izučava zanate i služi svoje poslodavce. Jedan od njih bio je Radiša Stanković iz Podključa, koji je učio tkački zanat i istovremeno služio učitelja Vlahotu Mihačevića za platu od 12 perpera i izdržavanje. ${ }^{124}$

120 DADU, Div. Not. sv. 24, f. 19r (15. IV 1442); Lam de for. sv. 16, f. 14r (20. IX 1442); Д. Ковачевић-Којић, Градска насељьа, стр. 93, нап. 40.

121 Nos Miglien Plauisich et Radogna Pribisalich de Cernica et Vuchaç Miochanouich confiteor quod super nos et omnia mea bona obligamus nos dare Radiç Grubaceuich ducatos quadraginta quatuor usque ad tres mensis proxime futuros [...]. DADU, Deb. Not. sv. 25, f. 158r (4. V 1450).

122 Н. Мандић, Српске породице војводства Светог Саве, стр. 340.

123 DADU, Lam de for. sv. 16, f. 61v (8. XII 1442); Д. Ковачевић-Којић, Градска насельа, стр. 213;Б. Храбак, Из старије прошлости Босне и Хериеговине, књ. IV, стр. 72.

124 D. Kovačević-Kojıć, Arhivsko - istorijska istraživanja Gornjeg Podrinja, Naše starine 14-15, Zavod za zaštitu spomenika kulture, prirodnih znamenitosti i rijetkosti Bosne i Hercegovine, Sarajevo 1981, str. 122-123. 
O kućnoj posluzi u srednjovjekovnom Dubrovniku napisani su brojni radovi, od kojih bi između ostalih istakli istraživanja B. Hrabaka i D. Dinić-Knežević. ${ }^{125}$

U svojstvu sluge u Dubrovniku je radio Brajko Stojković iz Cernice. On se obavezao februara 1386. godine da će služiti Budislava Pribojevića u periodu od dvije godine, za izdržavanje i novčanu naknadu od 18 perpera. ${ }^{126}$

Od izučavanih zanata zastupljeni su bili zlatarski, obućarski, berberski, tkački, krojački, podstrizački, suknarski i drugi. Dana 5. oktobra 1419. godine Radovac Ljutičić iz Dobrog polja iz Cernice dao je sina Vladoja, koji je imao oko 13 godina, da u Dubrovniku služi postolara Serđa u periodu od šest godina. Vladoje se obavezao da će tokom navedenog perioda paziti i čuvati stvari i dobra rečenog Serđa, koji se pak obavezao da će Vladoja izdržavati i učiti svome zanatu. Takođe, Serđo se obavezao da će na kraju službe Vladoju dati diplomu svoga zanata. Za postupke Vladoja jamčio je njegov otac Radovac. ${ }^{127}$

Jedan od najprestižnijih zanata svakako je bio zlatarski, koji neki istraživači smatraju svojevrsnom umjetnošću. Za razliku od drugih zanatskih vještina, mladići koji su izučavali za zlatara pored šegrtovanja morali su majstorima i da novčano plate svoje školovanje. Takav slučaj nije bio sa Vukićem Radonjićem iz Cernice koji je 25. oktobra 1458. godine sklopio ugovor sa zlatarom Stjepanom Martinovićem. Vukić Radonjić se obavezao da će deset godina služiti zlatara Stjepana Martinovića koji će ga istovremeno podučavati ovoj zanatskoj vještini. Tokom naznačenog vremena Vukić koji je stanovao kod rečenog Stjepana obavezao se da neće krasti i neće se udaljavati bez odobrenja, već će čuvati stvari i dobra rečenog Stjepana. Takođe

125 Душанка Динић-Кнежевић, Прилог Проучаваюа миграчија нашег становништва у Италију током XIII и XIV века, Годишњак Филозофског факултета XVI/1, Филозофски факултет, Нови Сад 1973, стр. 39-62; Д. Динић-Кнежевић, Миграиије становништва из јужнословенских земаль у Дубровник током среднег века, САНУ, Филозофски факултет, Нови Сад 1995; Б. Храбак, Момци из Херцеговине и Босне у дубровачком занатству, трговини и поморству у XIV, XV и XVI веку, Из старије прошлости Босне и Хериеговине, књ. I, Архивар, Београд 2003, стр. 144-180.

126 Braychus Stoycouich [...] ad standum cum Budislauo Priboeuich. DADU, Div. Canc. sv. 26, f. 27r (5. II 1386).

127 Radouaç Gluticich de Dobro Poglie de Cernica locauit filium suis Vladoie etatis tredecim vel circa [...]. DADU, Div. Not. sv. 13, f. 13v (5. X 1419). 
neće raditi nedozvoljene radnje, već će raditi kao dobar sluga. Zlatar Stjepan se obavezao da će Vukića držati u svojoj kući i neće sa njime grubo postupati već će ga paziti, izdržavati i učiti svome zanatu i neće ga iznevjeriti. Pored toga davat će mu nove haljine. Za postupke Vukića Radonjića jamčio je njegov brat Vukosav. ${ }^{128}$

Zlatarski zanat u Dubrovniku je učio i Radonja Radojević iz često pominjanog sela Korita pored Cernice. Njegov učitelj bio je Jovan Proganović, zlatar iz Novog Brda. ${ }^{129}$

Početkom jula 1462. godine Ratko Bogdanović iz Cernice iz Nevesinja obavezao se da će služiti i učiti krojački zanat kod Matka Rađenkovića u periodu od šest godina. ${ }^{130}$ Međutim, nije jasno dali je ovde riječ o grešci pisara ili je u srednjem vijeku odista postojalo selo Cernica u Nevesinju, danas nepoznato.

Mladi naraštaj koji je odlazio da služi i uči zanate, ukoliko se ne bi snašao u novoj sredini, vraćao se u Cernicu. Neki od njih pak ostajali su trajno u Dubrovniku, ženili se i dobijali dubrovačko građanstvo, poput Vukića Radoševića, Boguna Radosalića i drugih. ${ }^{131}$

Kada je riječ o materijalnim ostacima Cernice, od kulturno-istorijskih spomenika, izuzev stećaka i ruinirane tvrđave Ključ, gotovo da nije ostalo ništa iz srednjovjekovnog perioda. $\mathrm{Na}$ ovom području evidentirano je nekoliko crkvišta. Interesantno je pomenuti da je $\mathrm{u}$ naučnim radovima još u XIX i početkom XX vijeka zabilježeno predanje da je Jelena, kći srpskog kneza Lazara i supruga Sandalja Hranića, izgradila pet crkava u Cernici. Prije dvije godine, na lokalitetu Makov Val u Cernici stanovništvo je, nažalost samoinicijativno, bagerima vršilo iskopavanje, gdje su tom prilikom otkopali jednu od pomenutih crkava. Pred ulazom crkve otkopan je i srednjovjekovni spomenik i na njemu nepoznat uklesan natpis koji nas obavještava da na tom mestu leži knez Nikola Rašković Drobnjak, o čemu smo naučnu i čitalačku javnost upoznali u radu: "Задужбина Јелене

128 Stiepan Martinouich aurifex conduxit et acordavit Vochich Radognich de Zerniza [...]. DADU, Div. Not. sv. 42, f. 6r ( 25. X 1458).

129 DADU, Div. Not. sv. 43, f. 130v; Cvito Fisković, Dubrovački zlatari od XIII do XVII stoljeća, Starohrvatska prosvjeta, vol. III, Split 1949, str. 165.

130 Matchus Radienchouich sartor conduxit et acordavit Ratchum Bogdanouichde Zerniza de Neuesigne pro annos sex proxime futuros [...]. DADU, Div. Not. sv. 46, f. 75r (1. VII 1462).

131 Б. Храбак, Из старије прошлости Босне и Херцеговине, књ. IV, стр. 83. 
Лазаревић у Херцеговини". 132 Ubrzo poslije objavljivanja navedenog rada, pronašli smo u dokumentima Nikolu Raškovića Drobnjaka, evidentiranog 1453. godine kao dužnika, što smo i prezentovali na naučnom skupu, "Povijesno naslijeđe hercega Stjepana Vukčića Kosače", održanom 19. i 20. maja 2016. godine u Mostaru. ${ }^{133}$ Nakon toga je E. Kurtović objavio rad zasnovan na pomenutom izvoru: "Vlasi Drobnjaci i stećci...". U njemu je između ostalog pomenuti rad: "Задужбина Јелене Лазаревић у Херцеговини" ocijenio kao "neobična kombinacija dnevnopolitičke ostrašćenosti u radu s izvorima prvog reda". ${ }^{134}$ Međutim, ovakve tvrdnje jedino su jasne E. Kurtoviću, jer u pomenutom radu nema nijedne dnevnoplitičke riječi.

Stanovništvo Cernice i Ključa je šezdesetih godina XV vijeka, pod upravom Kosača, proživljavalo poslednje godine slobode. Tokom sukoba između hercega Stefana i njegovog sina Vladislava, Osmanlije su februara 1463. godine prodrle u Hercegovinu i stale na stranu Vladislava, kojem je herceg, pod pritiskom, dodijelio jednu trećinu njegovih posjeda. Cernicu i Ključ zauzele su Osmanlije. Zbog raznih manjkavosti u vojnim redovima, sultan je donio odluku o povlačenju, a u osvojenim oblastima ostavio je dio svojih vojnih snaga. $U$ takvim prilikama, herceg i njegov sin Vlatko krenuli su sa svojim odredima u oslobađanje teritorija. Jula 1463. godine oslobođen je Ključ i Cernica. ${ }^{135}$ Dvije godine kasnije (1465), Cernicu su ponovo okupirale Osmanlije. Nedaleko utvrđen grad Ključ odolijevao je napadima i uspješno je branjen pune tri godine. Pod komandom vojvode Ahmeta, Osmanlije su zauzele Ključ krajem avgusta 1468. godine, ${ }^{136}$ da bi 1468/1469, prilikom popisa stanovništva sandžaka Bosne, Cernica bila registrovana kao trg sa 81 domaćinstvom i 18 neoženjenih. ${ }^{137}$

132 Радмило Пекић, Задужбина Јелене Лазаревић у Хериеговини, Зборник радова XLIV (1), Филозофски факултет, Косовска Митровица 2014, стр. 371-384.

133 DADU, Div. Not. sv. 37, f. 76v-78 (7. VI 1453).

134 E. Kurtović, Vlasi Drobnjaci i stećci (Crtice o Nikoli Raškoviću i njegovim nasljednicima), Godišnjak, Centra za balkanološka ispitivanja, knj. 44, ANU Bosne i Hercegovine, Sarajevo 2016, str. 303-316.

135 М. Динић, Српске земле у средюем веку, стр. 259; С. Ћирковић, Стеббан Вукчић Косача и юегово доба, стр. 257; В. Атанасовски, Пад Хериеговине, стр. 17.

136 Hazim Šabanović, Bosanski pašaluk, Svjetlost, Sarajevo 1959, str. 44-45; M. Динић, Српске земте у средюем веку, стр. 245.

137 Aнmet Aličić, Sumarni popis sandžaka Bosne iz 1468/69. godine, Islamski kulturni centar, Mostar 2008, str. 61. 


\section{Cernica during Kosaca Reign}

\section{Summary}

Based on the published and unpublished sources from the Dubrovnik archives, as well as earlier field research, the paper presents, apart from the references to the past, economic and cultural position of the Cernica residents during the reign of the noble Kosaca family.

In the extant historiography medieval Cernica was recognized as one of the caravan stops on the 'Dubrovnik road'.

Cernica was ruled by the squires from the house of Kosaca starting from the 70 s of the $14^{\text {th }}$ century until 1456 , when it was incorporated into the Ottoman Empire. Duke Sandalj Hranic established the customs office in Cernica. As the time passed, Cernica became a trade centre. The market and the main residential area were situated in the Cernica field. Moreover, Cucenica, the place situated in the Cernica field, where medieval monuments were found, is even today referred to as Grad (town) or carsija (centre of the city) by the locals.

One of the most important residences of the noble Kosaca family was a nearby fortified town called Kljuc, in which Kosaca dukes welcomed ambassadors and issued them charters.

Sandalj Hranic and his heir Herzog Stefan Vukcic Kosaca controlled the road traffic that connected Dubrovnik with Bosnia and Serbia over Cernica and Kljuc. Merchants who used the 'Dubrovnik road' were robbed by the Kosaca's servants in Cernica and its nearby area, often with the permission from their masters.

The residents of Cernica were primarily involved in livestock farming and agriculture while some, to a lesser extent, were craftsmen. Surplus products from livestock farming and agriculture were exported to Dubrovnik.

Due to preserved trade contracts which the residents from Cernica signed in Dubrovnik, we can conclude that their business associates were usually butchers and fabrics manufacturers and merchants. Therefore, the export from Cernica largely focused on livestock, wax and other raw 
materials, while the import consisted from different fabrics and other goods. Businessmen from Cernica usually bought goods taking loans from the Dubrovnik investors.

Certain number of steles and sites of former churches are preserved as material remains from the medieval period. Steles from this area were removed and today they can be found at the museums in Sarajevo and Belgrade. A church, which was, according to the popular belief, built by Jelena Lazarevic, Sandalj Hranic's wife, has been excavated recently at the site of the orthodox cemetery in Makov Val.

Keywords: Cernica; Kljuc; Kosaca; Sandalj Hranic; Stefan Vukcic; Dubrovnik. 